\title{
Origins of the Problematic Substances in Fines, for Their Acceptance at Inert Landfills
}

\author{
Soukaina Oujana, Denis Sanchez \\ Université Grenoble Alpes, CNRS, G-SCOP, Grenoble, France \\ Email: Soukaina.oujana@grenoble-inp.fr
}

How to cite this paper: Oujana, S. and Sanchez, D. (2018) Origins of the Problematic Substances in Fines, for Their Acceptance at Inert Landfills. Journal of Geoscience and Environment Protection, 6, 237-246.

https://doi.org/10.4236/gep.2018.65020

Received: April 11, 2018

Accepted: May 27, 2018

Published: May 30, 2018

Copyright $\odot 2018$ by authors and Scientific Research Publishing Inc. This work is licensed under the Creative Commons Attribution International License (CC BY 4.0).

http://creativecommons.org/licenses/by/4.0/

\begin{abstract}
Integrated solid waste management (ISWM) involves approaching solid waste in a comprehensive manner with careful selection of appropriate technology. The aim of good waste management is to push waste up the hierarchy with landfill as a last resort. However given the current sorting technology, heterogeneous residues called Fines are created, they are considered at the present time as non-sortable and non-recoverable sent to second class landfills. A previous conducted study has revealed that fines contain several problematic substances for an inert classification. This article summarizes the most important problematic substances in fines for their acceptance inert landfills. These substances were identified by analyzing several samples collected from a siting of non-hazardous solid waste in the region of Rhône-Alpes in France. Eluate Analysis and fines analysis were conducted in order to identify the presence of any component that could prevent the classification of fines in an inert landfill. The obtained results were compared with the limit values for waste acceptance in an inert landfill. The study concluded that the six top-ranking problematic substances are Copper, Mercury, Antimony, Chloride, Fluoride and Sulfates, this study gives additional information on the origins of these substances that deserves particular attention to better limit their presence in the input of fines stream.
\end{abstract}

\section{Keywords}

Fines, Heavy Metals, Inert Waste, Landfill, Non-Hazardous Waste

\section{Introduction}

According to the waste management hierarchy, landfilling is the least preferable option and should be limited to the necessary minimum [1]. A landfilling site refers to an area of land where waste is placed for permanent disposal. The pri- 
mary objective of landfill site is to provide effective control measures to prevent or reduce as far as possible negative effects on the environment, in particular the pollution of surface water, groundwater, soil and air, as well as the resulting risks to human health arising from landfilling of waste [2].

There are many costs of sending waste to landfill, from environmental to social and financial [3]. The average price to landfill a ton of ISW in France is $3-5$ $€ \mathrm{HT} / \mathrm{t}$ for inert waste, 50 - $100 € \mathrm{HT} / \mathrm{t}$ for non-hazardous waste and reach prices higher than $500 € / \mathrm{t}$ for hazardous waste storage facilities. These are orders of magnitude because the costs vary according to the nature of the waste and any pollutant cause additional costs of stabilization. The Landfill Directive defines the different categories of waste (hazardous waste, non-hazardous waste and inert waste) and applies to all landfills, defined as waste disposal sites for the deposit of waste onto or into land. Landfills are divided into three classes: landfills for hazardous waste, landfills for non-hazardous waste, and landfills for inert waste [4].

Inert waste means waste that does not undergo any significant physical, chemical or biological transformations. Inert waste will not dissolve, burn or otherwise physically or chemically react, biodegrade or adversely affect other matters with which it comes into contact in a way likely to give rise to environmental pollution or harm human health. The total leachability and pollutant content of the waste and the Eco toxicity of the leachate must be insignificant, and in particular not endanger the quality of surface water and/or groundwater [5].

Any waste destined to landfill needs to respect the WAC established under the EU Landfill Directive [6]. These criteria mainly relate to the presence of hazardous substances which might leach out in landfill. This study focuses on the acceptance of the shredding residues of NHW for inert landfills. The main issue, of the waste management unit under study was the composition of fines mixture (Figure 1 and Figure 2), it contains different types of materials: wood, polystyrene,

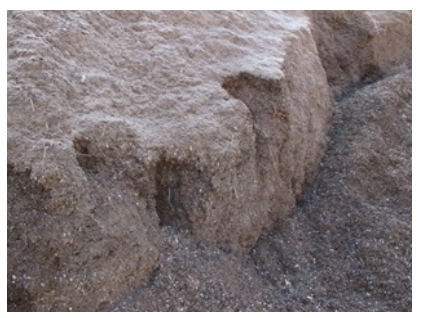

Figure 1. Pile of fines.

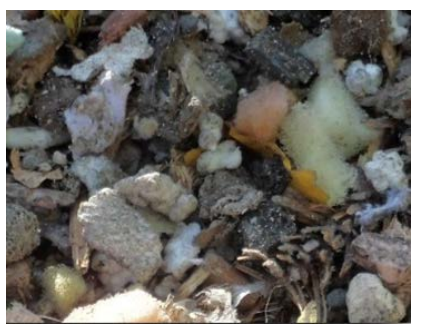

Figure 2. A zoomed sample of fines, fines' pile $\times 10$. 
rubbles, plastic, foams, textiles, metals... At the present time it is destined to second class landfill center, dedicated to storage non-hazardous but not inert waste, without any recovery way. Fines typically consists of two different categories, firstly $38 \%$ of organic materials that include foam, paper/cardboard and wood and $40 \%$ of inert materials (Glass, rubble). This means that the organic part of the fines mixture should be evaluated with the TOC indicator and verified if it is therefore not problematic for inert classification. This study focuses on the substance characterization of fines, which has a great importance in gathering useful, accurate, and appropriate information on the nature of the suitable landfill site.

\section{Inert Waste Acceptance Criteria}

The Landfill Directive sets rigorous standards to reduce both our reliance on landfill and the environmental impact of wastes disposed for landfill. Waste that does not meet the above criteria cannot be accepted at landfill for inert waste:

- The TOC indicator (respect the limits on the organic content of the waste);

- It is not hazardous waste ( respect the limits of the leachability);

- It does not exceed the limit values provided in Table 1.

\section{Definition of TOC (Total Organic Carbon)}

NHS Fines contain a large variety of organic materials ranging from paper to wood. Important characteristics of the organic matter include their ability to hold water, and emit leachate [7]. As a result of these characteristics, the determination of total organic carbon is very essential, since its presence or absence can highly influence how chemicals will react in the soil or sediment. TOC is an indicator of organic presence. It allows evaluating the amount of volatile or non-volatile organic components in a sample. The carbon elements are oxidized at a temperature of $950^{\circ} \mathrm{C}$ in the presence of catalysts. The $\mathrm{CO}_{2}$ formed is measured by an infra-red analyzer [8]. Total Organic carbon contents may be used qualitatively to assess the nature of the organic materials contained in fines.

For an inert classification. The fines sample must have a TOC indicator less than $5 \%$ which is equal to $50,000 \mathrm{mg} / \mathrm{kg} \mathrm{DW}$, The TOC content was measured

Table 1. Pile of fines.

\begin{tabular}{cc}
\hline DW & Dry Weight \\
\hline ISWM & Industrial solid waste Management \\
IWL & Inert Waste Landfills \\
NHSF & Non-Hazardous Solid Fines \\
NHWL & Non-hazardous waste Landfills \\
SF & Soluble Fraction \\
TOC & Total Organic Carbon \\
WAC & Waste Acceptance Criteria \\
\hline
\end{tabular}


for six different solid samples according to the technique explained previously. The analysis results shown that TOC of fines have values between $1.5 \%$ and $5 \%$ for an average of $3 \%(30,000 \mathrm{mg} / \mathrm{kg} \mathrm{DM})$. Based on these results, we concluded that fines mixture respects therefore the standards for admission to inert landfills.

Knowing that the organic part of the "Fine" mixture is therefore not problematic for an inert classification, the aim was to identify substances that could prevent fines for a classification in inert landfills. Knowing that the organic part of the "Fine" mixture is therefore not problematic for an inert classification, the aim was to identify substances that could prevent fines for a classification in inert landfills.

\section{Acceptance of Fines for Inert Landfills}

\subsection{The Limit Values for Inert Classification}

Table 2. Fines' substance characterization.

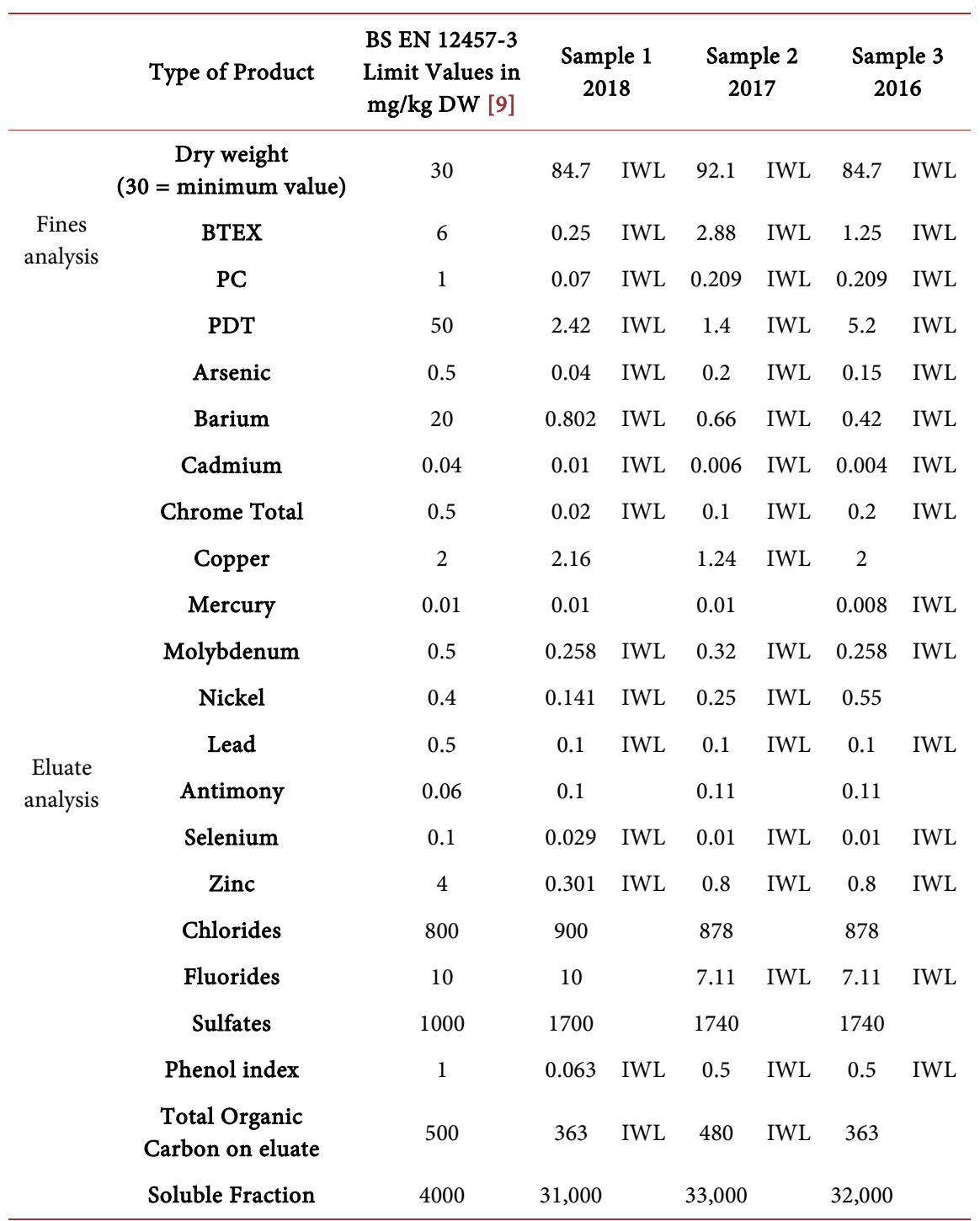




\subsection{Results and Discussion}

Table 2 shows the results of analysis made on three samples of fines. Sample preparation techniques were performed following the laboratory practices. The results have shown the presence of several elements in the mixture of fines that prevent their classification for IWL. They consist of: copper, mercury, antimony, chloride, fluoride, sulfates $\left(\mathrm{SO}_{4-2}\right)$ and the soluble fraction.

Copper, mercury, antimony, chlorides and fluorides hardly exceed their respective authorized limit values, while sulfates and the soluble fraction (SB) largely exceed the limit values with an average value of $1000 \mathrm{mg} / \mathrm{kg}$ DW for $\mathrm{SO}_{4-2}$, and $4000 \mathrm{mg} / \mathrm{kg} \mathrm{DW}$ for the SB. The latter represents the dry residue and corresponds to the remaining leachate (leaching test) after evaporation of the eluate at $105^{\circ} \mathrm{C}$. Leaching was known as lixiviation, it is the process by which soluble constituents are dissolved and filtered through the soil by a percolating fluid, while percolation can be described as the movement of water downward and radially through subsurface soil layers, continuing downward to groundwater [10]. Thus, when fill materials come into contact with liquid constituents in the solid phase will dissolve into the liquid forming a leachate (US EPA, 1997 in ADEME, 1999) [11]. The leaching allows identifying the pollutants contained in the raw sample (in these case fines). The solid fraction allows determining the presence of mineral pollutants. Based on fines analysis, the solid fraction largely exceeds the limit values. This means that there is a real interest to determine the origin of problematic substances (Table 3), in order to identify technologies allowing extracting them from the stream of fines.

\subsection{The Origin of the Problematic Substances}

\subsubsection{Antimony $(\mathrm{Sb})$}

Antimony is a naturally occurring, silvery-white, hard, brittle metal. It is also formed as a by-product of smelting Lead and other metals. It is used in alloys with Lead and other metals, electric storage batteries, solder, sheet and pipe metal, castings and pewter. Sb is known that it is mainly used for its flame retardant properties, it is therefore found in the sheaths of electrical wires and cables and also in some types of glasses that contain pigments. Antimony and its compounds are considered to be priority pollutants interest by the USEPA and the $\mathrm{EU}$ [12]. As a result the aim is to reduce the presence of antimony in order to respect the limit value for an inert classification $(0.06 \mathrm{mg} / \mathrm{kg} \mathrm{DW})$. This means that there is a real interest in extracting these elements from the input fines stream in order to reduce the amount of antimony and thus respect the limit value for a classification in IWL.

\subsubsection{Chloride $\left(\mathrm{Cl}^{-}\right)$}

Chloride is mainly contained in PVC and glue for plywood. Some IWM centers have a bucket dedicated exclusively to PVC, however, the bulky bucket accepts furniture and several products composed entirely or partly of PVC. It has a high 
Table 3. Problematic substances for IW classification and their origins.

\begin{tabular}{|c|c|}
\hline Substances & Origin \\
\hline Antimony & $\begin{array}{l}\text { - flame retardants in the sheaths of electric cables } \\
\text { - Textiles, rubber and adhesives } \\
\text { - Plastics: auto bumpers, recyclable bottles, geotextiles } \\
\text { - Metals: welds, sheets, pipes } \\
\text { - Pigments of glass, ceramic, porcelain, Paintings } \\
\text { - Lubricants: discs and brake pads } \\
\text { - Photovoltaic cells, plasma screens }\end{array}$ \\
\hline Chloride & $\begin{array}{l}\text { - Polyvinyl chloride (PVC) } \\
\text { - Ammonium chloride } \\
\text { ○ Plywood glues } \\
\text { ○ Textile dyes }\end{array}$ \\
\hline Copper & $\begin{array}{l}\text { - Electric cables and WEEE equipment } \\
\text { - Household appliances (cooking utensils) } \\
\text { - Plumbing hoses, Roofs and gutters, keys and locks and decoration elements }\end{array}$ \\
\hline Fluoride & $\begin{array}{l}\text { - Production of steel, glass, enamel, aluminum, alkyls and chlorofluorocarbons } \\
\text { - Toothpaste, Cleaners } \\
\text { - Soluble in water and organic solvents such as benzene }\end{array}$ \\
\hline Mercury & $\begin{array}{l}\text { - Bulbs: energy saving, tungsten filaments and fluorescent tubes } \\
\text { - Button cells (watches, car keys, calculators, toys, gadgets ...) and accumulators } \\
\text { - Measuring and control devices for individuals, industries and medical } \\
\text { establishments: thermometers, barometers and manometers, hydrometers, } \\
\text { flow meters, level meters and some thermostats } \\
\text { - Presence in some WEE, battery chargers, toggle switches, Photocopier } \\
\text { - Mercury is also used for the production of PVC, polyurethane foams and } \\
\text { chlorinated alkalis. } \\
\text { - Mercury is a natural product of coal burning, slags contain mercury in a small } \\
\text { amount. }\end{array}$ \\
\hline Sulfate & $\begin{array}{l}\text { - Gypsum (raw material for the manufacture of plaster) } \\
\text { - Building and demolition materials }\end{array}$ \\
\hline Soluble fraction & $\begin{array}{l}\text { It is very difficult to evaluate what is in the soluble fraction. It is mainly mineral } \\
\text { salts } \\
\text { - Cations: } \mathrm{Na}, \mathrm{K}, \mathrm{Mg}, \mathrm{Ca}, \mathrm{Si} \\
\text { - Anions: } \mathrm{CO}^{3}, \mathrm{HCO}^{3}, \mathrm{Cl}^{-}, \mathrm{SO}^{4}\end{array}$ \\
\hline
\end{tabular}

amount of energy which presents an advantage for its combustion, however a complete understanding of the chloride chemistry and behavior must be known as they play a dynamic role in the production of acid gases and dioxins [13]. As regards the glue for plywood, it is necessary to consider a more selective sorting of the wood with an aeraulic sorting or a gravity table in order to extract the part of chloride contained in the stream of fines. The technical and economic feasibility of this solution must be taken into consideration.

\subsubsection{Copper (Cu)}

$\mathrm{Cu}$ cannot be disposed of in its present form and therefore requires treatment to stabilize it or make it inert prior to disposal [14]. Copper is very easily recycled and is an endangered raw material. It is contained in electrical systems: WEE, electronic toys, gadgets, etc. The permissible limit for an inert landfill acceptance 
is $2 \mathrm{mg} / \mathrm{kg} \mathrm{DW}$. The three fines samples have a concentration between 2.16 $\mathrm{mg} / \mathrm{kg} \mathrm{DW}$ and $1.24 \mathrm{mg} / \mathrm{kg}$ DW. The limit value, in two samples, is not crossed except the sample 1 , where it is slightly exceeded.

$\mathrm{Cu}$ presence in fines, can be explained by the presence of small electrical circuits inside some bulky waste or due to sorting errors.

\subsubsection{Mercury (Hg)}

Mercury has many benefits for the industry and society but it is also extremely poisonous for man and the environment it is a dangerous substance [15] [16]. As a result, any waste containing mercury must be considered hazardous. $\mathrm{Hg}$ in the regulation of waste is regarded as a dangerous substance which, when contained in waste, is one of the properties, leading to a classification of waste as hazardous [17]. Mercury is used as a metal and compound for numerous industrial and household-related applications, such as the following (for liquid mercury): electrodes in chlorine-alkali equipment; electrical switches; thermometers; barometers; manometers. Liquid mercury is also used in fluorescent light bulbs (elemental mercury adsorbed at the fluorescent powder) and amalgam, nearly half of which is composed of mercury [18].

In our case, When the entering stream contain batteries, fluorescent lamps and other sources of mercury disposed in Table 3 because of sorting errors, Fines could contain $\mathrm{Hg}$, in addition to gypsum the raw material of plaster, and cause the exceeding of the limit value in sulfate, naturally contains mercury in small quantity. In this context the aim is to extract the plaster from the bulky bucket in order to eliminate the sulfate contained in the fines and, perhaps, a part of the mercury.

\section{The French Legislation for the Soluble Fraction}

\subsection{Preparation of the Sample}

The steps to obtain the soluble fraction are:

- The shredding of the sample and passing through a $0.45 \mu \mathrm{m}$ sieve. $95 \%$ of the sample's weight must pass through the sieve, otherwise the sample cannot be admitted for the soluble fraction test.

- Leaching test: meets the NF EN 12457-2 standard. The raw sample is put into a volume of water with a liquid/waste ratio equal to $10 \mathrm{l} / \mathrm{kg}$ (this ratio is also used on polluted soils and is called "Ration L/S"). The wet sample is then stirred for 24 hours and decanted for 30 minutes. Finally the sample goes to the oven at $105^{\circ} \mathrm{C}$. The remaining dry residue is the soluble fraction. Another name of this one is "Dry residue at $105^{\circ} \mathrm{C}$ ". The soluble fraction is obtained and the conductivity of the sample is also calculated. There is a correlation factor between the conductivity and the soluble fraction by a factor of 10 .

\subsection{Conductivity}

The legislation requires a soluble fraction less than $4000 \mathrm{mg} / \mathrm{kg} \mathrm{DM}$, and a conductivity less than $400 \mathrm{Sm}^{-1}$. The soluble fraction test may have certain errors. 
Very fine particles generated by the preparation, or staining persistence of the sample could cause these errors. In this case it is normal to have a soluble fraction of several thousand $\mathrm{mg} / \mathrm{kg}$ (Higher than the limit value) and a conductivity lower than the imposed limit of $400 \mathrm{~S} \cdot \mathrm{m}^{-1}$. As a result, a test must be conducted in order to evaluate the soluble fraction. Two methods are then proposed: a second leaching test and a percolation test. The percolation test is the one preferred. It allows getting the real soluble fraction of the sample and not the one influenced by the presence of staining persistence.

The percolation test allows establishing, in case of inconsistency between the values of the conductivity and the soluble fraction, the real value of the soluble fraction. If, after the first leaching test, conductivity is greater than $400 \mathrm{Sm}^{-1}$ AND soluble fraction above $4000 \mathrm{mg} / \mathrm{kg} \mathrm{DM}$ is obtained, it is possible to conclude directly that the value of the soluble fraction is good and therefore exceeds the limit allowed for an IW classification. Conductivity is therefore a parameter that gives access to the soluble fraction and that must be integrated into the analysis to be performed in the laboratory.

The Soluble Fraction of fines consists of several substances that are difficult to eliminate (Table 3). In this study mercury, antimony, chlorides and fluorides are minor and hardly exceed their respective authorized limit values while sulfates largely exceed the limit value. The aim is to focus on sulfates since their origin in fines stream is easily identifiable and consists only of gypsum, plaster.

\section{Conclusions}

Small amounts of heavy metals are common in our environment and are actually necessary for good health, but large amounts of any of them may be considered as hazardous. Research on fines, revealed that they contain major and minor amounts of heavy metals. They consist of: Copper, Mercury, Antimony, Chloride, Fluoride and Sulfates. Their prevalence can be explained by large portion of WEE in bulky waste, or sorting errors. A list of all the problematic substances and their origins was given. In addition, as part of the research, some suggestions of possibilities of their extraction were given.

The concentration of sulfates is 7 - 9 times higher than the limit value, while the other substances slightly exceed the legal required limit for IW classification. Based on this it was concluded that the extraction of the product containing sulfates might become of interest for extraction in more or less near future, Meanwhile fines could not be landfilled in an inert waste storage facility because of the presence of heavy metals and should be disposed in a class 2 landfill center.

Knowing that the presence of heavy metals could be a result of sorting errors, and as individuals we would suggest to encourage communication with the users of waste disposal centers, IWM units, partners and clients. Even though rules and procedures for waste sorting are provided, it does not guarantee that people sort waste according to them. Waste sorting behavior needs to be examined directly to observe if the guidance and procedures are effective, as well as to dis- 
cover ways to make them more effective.

\section{References}

[1] Landfill Waste-Environment-European Commission. http://ec.europa.eu/environment/waste/landfill_index.htm

[2] Oluwapelumi and Ojuri, O. (2015) Geotechnical Characterization of Some Clayey Soils for Use as Landfill Liner.

http://www.miljodirektoratet.no/en/Legislation1/Regulations/Waste-Regulations/C hapter-9/

[3] M\&K Group (2015) The Costs of Sending Waste to Landfill. M\&K, 28-Sep-2015.

[4] Eva, B. and Elin, L. (2017) Plug the Marine Litter Tap: A Pilot Study on Potential Marine Litter Sources in Urban Areas. Nordic Council of Ministers, Copenhagen.

[5] Irem, S., Adrian, M.L., Agron, H., Ahmet, C.K., Boban, B., Danijela, D., Desislava, S., Dragan, L., Gani, B., Irina, L. and Miodrag, G. (2014) Report: Benchmarking on Solid Waste Management in South-East Europe 2015. NALAS.

[6] Hjelmar, O. and Nordic Council of Ministers (2009) Treatment Methods for Waste to be Landfilled. Nordic Council of Ministers, Copenhagen.

[7] Schumacher, B.A. (2002) Methods for the Determination of Total Organic, Carbon(TOC) in Soils and Sediments.

[8] https://www.dictionnaire-environnement.com/carbone_organique_total_cot_ID719 $\underline{. h t m l}$

[9] Michel, L (2010) Arrêté du 28 octobre 2010 relatif aux installations de stockage de déchets inertes.

[10] Dawson, A. (2008) Water in Road Structures: Movement, Drainage \& Effects. Springer Science \& Business Media, Berlin.

[11] Science Applications International Corporation Washington State Department of General Administration (2003) An Assessment of Laboratory Leaching Tests for Predicting the Impacts of Fill Material on Ground Water and Surface Water Quality. Washington State Department of Ecology.

[12] Filella, M., Belzile, N. and Chen, Y.-W. (2002) Antimony in the Environment: A Review Focused on Natural Waters: I. Occurrence. Earth-Science Reviews, 57, 125-176. https://doi.org/10.1016/S0012-8252(01)00070-8

[13] Penque, A. (2007) Examination of Chlorides in Municipal Solid Waste to Energy Combustion Residue: Origins, Fate and Potential for Treatment. Department of Earth and Environmental Engineering Fu Foundation of Engineering and Applied Science, Columbia.

[14] Coruh, S., Ergun, O.N. and Cheng, T.-W. (2006) Treatment of Copper Industry Waste and Production of Sintered Glass-Ceramic. Waste Manag. Res. J. Int. Solid Wastes Public Clean. Assoc. ISWA, 24, 234-241. https://doi.org/10.1177/0734242X06062600

[15] Cheng, H. and Hu, Y. (2012) Mercury in Municipal Solid Waste in China and Its Control: A Review. Environmental Science \& Technology, 46, 593-605. https://doi.org/10.1021/es2026517

[16] (2018) Mercury Retort and Processing Waste Management. https://www.wmsolutions.com/solutions/mercury-processing/

[17] Mukherjee, A.B., Zevenhoven, R., Brodersen, J., Hylander, L.D. and Bhattacharya, 
P. (2004) Mercury in Waste in the European Union: Sources, Disposal Methods and Risks. Resources, Conservation and Recycling, 42, 155-182.

https://doi.org/10.1016/j.resconrec.2004.02.009

[18] Lehmphul, K. (2014) Waste Containing Mercury. Umweltbundesamt. http://www.umweltbundesamt.de/en/topics/waste-resources/waste-management/wa ste-types/hazardous-waste/waste-containing-mercury 